\title{
ANALYSIS OF INVESTMENT LEVEL AND MARINA CERTIFICATION IN THE PROCESS OF RAISING SAFETY STANDARDS ON THE WEST POMERANIAN SAILING ROUTE
}

\section{TOMASZ ZALEWSKI, ${ }^{1}$ MAGDALENA BULIKOWSKA ${ }^{2}$}

\author{
${ }^{1}$ University of Szczecin Faculty of Earth Sciences, Laboratory of Water Safety, POLAND \\ e-mail: tomasz.zalewski@usz.edu.pl \\ ${ }^{2}$ Marshal's Office of the West Pomeranian Voivodship, POLAND \\ e-mail:magda_bulikowska@poczta.onet.pl
}

RECEIVED
ACCEPTED
JEL
CLASSIFICATION

KEYWORDS

ABSTRACT
10 December 2018

28 December 2018

L83, R40, R41, Z30, Z31

management, yacht port, marina, safety, certification, EU funds, tourism

The aim of this article was a detailed analysis of the level of investment and certification of marinas in the process of raising safety standards on the West Pomeranian Sailing Route. The first chapter describes the sailing market in Poland and West Pomerania together with the justification of needs, which was the foundation for creating a program for the development of port infrastructure and marinas in the West Pomeranian region in the Oder, Szczecin Lagoon on the Baltic Sea coast areas. The list of investment amounts allowed to determine average indicators of investment effectiveness in berths. The next chapter describes the original certification system "Bursztynowe Kotwice" [Amber Anchors] implemented by the Union of Ports and Yachts, focusing on safety-related criteria and then analyzes the 13 marinas certification on the West Pomeranian Sailing Route in the context of the achieved certification level and comparison of the number of tourists visiting this marina in the years 2015-2016. It was found that marinas that underwent certification recorded an increase in the number of yacht visitors. The incurred investments allowed to meet the minimum standards for the quality of services and safety in marinas.

\section{Introduction}

Sailing is one of the most popular forms of tourism. It combines relaxation, challenge, sport and fun. Factors that allow the development of sailing are desirable and valued by regions that have a large amount of water resources, both inland waters and sea. 
In Poland, the leaders among tourist regions, including those in which the sailing base is intensively developed, include the West Pomerania region. Among the 16 Polish regions, the largest number of overnight stays of Polish and foreign tourists is recorded in West Pomerania, which is the best confirmation of the above-average tourist attractiveness of the area (stat.gov.pl). An important element of the tourist offer of the West Pomerania are coastal and inland marinas and ports. The analysis of the quality of the tourist offer in this area is possible thanks to the system of evaluation during certification, which individual locations are subjected to in the region. Certification, in addition to the confirmation of the quality of services, also confirms that the facility meets high requirements in terms of marina access and berth. According to the researchers of the subject, safety is one of three factors (apart from nautical and sailing assets and available ports) that determine the attractiveness of a given water body (Butowski, 2010, pp. 95-114).

The need for safety is one of the most important and the most felt needs for every human being. It is also visible in those spaces in which the need to ensure safety concerns both the obligation to ensure safety for employees and special care for the life and health of recipients of services provided. Operators of marina understand this need and look for means to improve the quality of their facilities. Taking care of the comfort and safety of visitors results in increased confidence of domestic and foreign tourists proved by increased demand and obtaining significant economic effects.

\section{The nautical market in Poland and West Pomeranian region}

The Polish nautical market is a growing industry that is catching up in the development of both sailing infrastructure and services. The diversity of Polish reservoirs requires a separate approach to the minimum requirements for the equipment of marinas, harbors and ports in the inland (e.g. Masuria) and those that are located in the area of sea waters (Baltic Sea, Szczecin Lagoon). The West Pomeranian Voivodship belongs to the privileged regions in Poland in terms of both the natural layout of inland waterways exploited by shipping (Strategy for the development of the transport sector of the West Pomeranian Region until 2020, 2010) and access to the sea, from the land side, inter alia through the Szczecin Lagoon, where the shipping route is the beginning of an adventure with sea water due to large waves and frequent haze (Woś, 2005, p. 85).

The relatively easy access to sailing on the Masurian lakes and skills perfected in inland waters make sailing on sea waters a challenge. In addition to the popularity of the West Pomeranian voivodship as one of the five regions most willingly visited by tourists in Poland, it is easy to understand the need for investments with high expenditure to bring a new order and quality into the nautical tourism space in the West Pomeranian Voivodship.

The West Pomeranian Sailing Route is the only network-based tourism product in Poland that has a strong impact on the surrounding and economy of the entire region, the implementation of which is followed by specific economic effects, both measurable and unmeasurable. Among them, the security level of nautical infrastructure and waterfronts, treated comprehensively in the region, is clearly distinguished. In 2008, at the request of the Marshal's Office of the West Pomeranian Voivodship, a document entitled "Program for the development of port infrastructure and marinas in the West Pomeranian Voivodship in the Odra region, Szczecin Lagoon at the Baltic Sea coast" (www.turystyka.wzp.pl) was prepared, which was the basis for supporting infrastructure investments for typically sailing and accompanying infrastructure for locations forming the West Pomeranian Sailing Route. These locations are shown on Figure 1. 


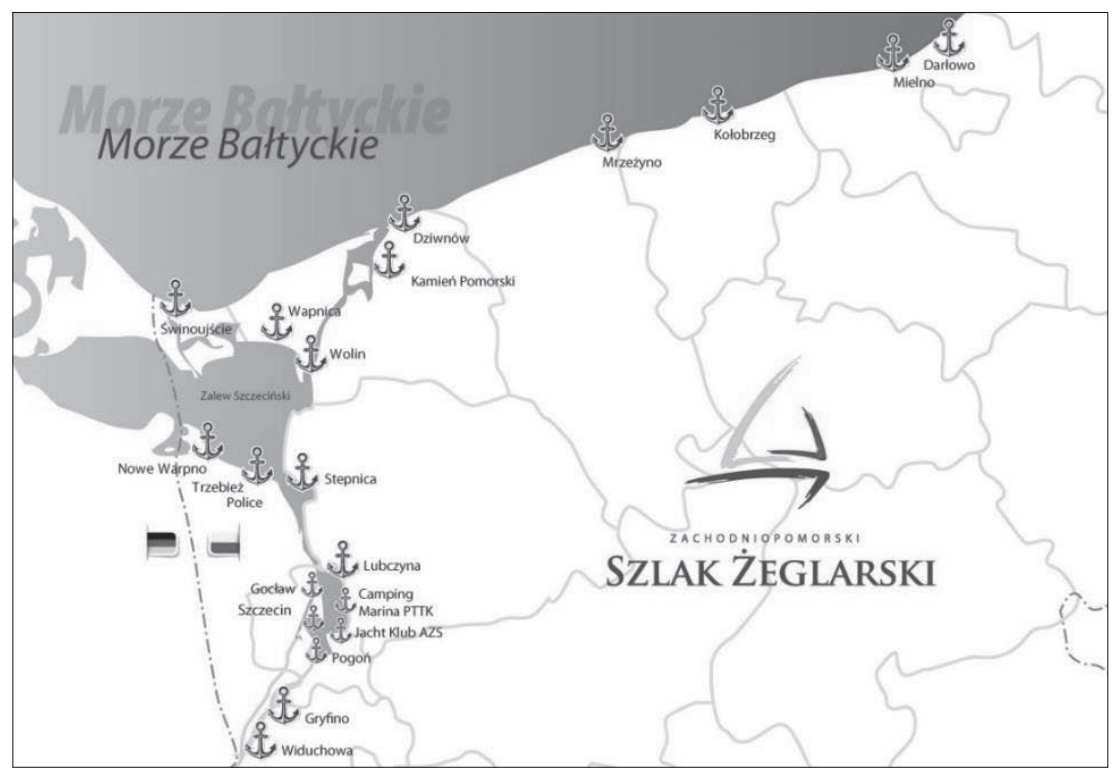

Figure 1. Marinas and ports on the West Pomeranian Sailing Route

Source: Association of Ports and Yachts - Local Tourist Organization of the West Pomeranian Sailing Route.

The importance and scale of the venture is demonstrated by the inclusion of some investments in the Individuate Indicative List under RPO WZ 2007-2013 (rpo2007-2013.wzp.pl) and limiting the possibility of supporting projects participating in tenders announced in competition modes only to facilities that have been included in the document as necessary to strengthen the network structure of sailing ports in the region (rpo2007-2013.wzp.pl). The projects supported, among others, the infrastructure of marinas, harbors and ports, infrastructure of berths, access to utilities (e.g. water and electricity, etc.), hardening of stopping places for yachts, sanitary facilities and social rooms (laundries, kitchens, technical facilities for users), infrastructure enabling the collection of sewage and sewage, parking lots, communication routes, multimedia kiosks, port fencing, monitoring systems, equipment of facilities with wireless Internet, technical infrastructure - cranes for yachts and boats, recreational areas within ports and marinas (playgrounds, etc.), small architecture - benches, sheds, barbecues, etc., purchase of equipment to improve safety and technical equipment of ports and marinas of the West Pomeranian Sailing Route, improving the accessibility of marina ports infrastructure and marina on the water side. Some of these requirements meet the highest safety requirements for modern yacht ports. The amount of funds invested in the development of nautical infrastructure in the West Pomerania Province is presented in Table 1.

Thanks to the invested funds, 2,310 berths have been supplemented with new basic and accompanying infrastructure. By applying a simple cost-effectiveness ratio, understood as the number of berths created for all the funds invested, it can be stated that the creation of one berth consisting of all necessary infrastructure during berthing, is the cost of PLN 98,348.73. This value decreases as the number of berths increases. 
Table 1. The amount of financial resources invested in the development of nautical infrastructure in the West Pomeranian Voivodship

\begin{tabular}{lr}
\hline \multicolumn{1}{c}{ Name/Location } & Invested funds (PLN) \\
\hline Marina Pogoń & $4,551,370.30$ \\
Yacht Club AZS & $2,112,291.56$ \\
Marina Wapnica - Międzyzdroje & $9,517,910.13$ \\
Yacht Port in Nowe Warpno & $9,675,981.27$ \\
Marina Wolin & $5,197,818.00$ \\
Marina Kamień Pomorski & $20,565,694.79$ \\
Marina at Wyspa Grodzka & $62,453,534.56$ \\
Euroregional Center for Water Education and Sailing & 36324639.98 \\
Water nooks in the area of Lake Dabie & $1,362,515.28$ \\
Marina Solna in Kołobrzeg & $11,432,247.10$ \\
Yacht Port in Dziwnów & $10,552,292.18$ \\
Yacht Port in Darłowo & $1,971,161.91$ \\
Basen Północny [North Basin] & $12,721,944.54$ \\
Yacht Port in Stepnica (all localisations) & $12,642,847.01$ \\
Yacht Port in Lubczyna & $7,408,761.31$ \\
Passenger quay in Gryfino & 14872331.26 \\
Passenger quay at Jana z Kolna in Szczecin & $1,118,017.27$ \\
Yacht Port in Police & $1,962,296.21$ \\
Yacht Port in Dabie - Marina Hotele & $1,041,902.25$ \\
\hline Total & $227,185,556.91$ \\
\hline Source: own study
\end{tabular}

Source: own study based on data obtained from the Marshal's Office of the West Pomeranian Voivodship and the West Pomeranian Regional Tourist Organization.

\section{The "Amber Anchors" certificeation system}

Trends in the market of sailing services indicate that the number of people owning their yachts in the coming years will remain relatively stable. The possible increase will be insignificant, which means that it is necessary to differentiate marketing methods and tools that attract sailors to a given destination, and later - to a specific port.

The promotion of the infrastructure, including the original certification program, supplemented the infrastructure of the West Pomeranian Sailing Route. Certification of marinas is a response to demand of recipient for independent confirmation that the facility meets certain quality requirements, assessed in various categories. The quality itself is feeling that something is good or bad. This is a subjective impression, depending on many factors, but professional, independent verification of standards considered universally important in feeling a sense of safety, allows to determine certain independent, objective requirements. Compliance with certain standards is a confirmation of quality, and safety plays a major role in quality. In the case of visiting seaports, the measure of safety, confirmed as a consequence of the certificate, is the measure of satisfaction of customers visiting a given port, reflected in the number of visitors.

Generally, the certificates confirm that the offered product or service meets the requirements defined by the standards - it is in accordance with the standards adopted for the given field. While no certification system has a problem in auditing goods or infrastructure, auditing services is a more complicated matter. The level of service 
quality can usually be assessed only at the time of their performance. Hence, the examination of the quality of mystery client services is already becoming so important and increasingly popular at the audit stage. This method is the third stage of certification of marinas and sailing ports in the "Amber Anchors " system (www.marinas.pl/ certification). Thanks to this, the visitor is sure that at any time he will receive the service at a certain level.

The "Amber Anchors" certification system is an original program of the Union of Ports and Yachts - the Local Tourist Organization of the West Pomeranian Sailing Route (ZPiPJ - LOT ZSŻ), which was developed after analyzing the most popular marina certification systems in the world. The success of using a given system lies in the possibility of implementing it to the conditions of a given country. Certification programs operating in the world could be too demanding, especially in relation to the price of obtaining a certificate and its later recertification, for the stillgrowing nautical market in Poland. "Amber Anchors" is a system that meets European standards and international customer requirements, adapted to Polish conditions. Its aim is to assess and classify the Westin Marine Route marinas and stimulate them for further development.

The certification process consists of four stages. Stage 1 is an objective evaluation, or classification of the marina, based on its infrastructure, into one of five categories. Evaluation takes place in 7 generic groups. Stage 2 is a subjective evaluation, consisting in checking the facility condition in terms of meeting the same criteria, which are evaluated by the zero-bin system in stage 1, by an independent inspector. After the evaluation, the results of stages 1 and 2 are compared. In the event of a difference in evaluation to the detriment of stage 1 (the results of the subjective evaluation indicate a lower category), the category indicated in step 2 is granted. In this case, the marina operator has the right to appeal against the decision of the certifying entity within 30 days from the receipt of the evaluation. Stage 3 is a mysterious client's visit. This stage concerns marinas that received at least two Amber Anchors. The visit takes place once a year and is aimed at checking the quality of services and cleanliness in the marina (including the quality of safety), in accordance with the requirements appropriate for the given category. Stage 4 is customer reviews. Marinas categorized with a minimum of 2 Amber Anchors are required to submit 10 anonymous surveys once a year, filled by sailors visiting the marina. The evaluation concerns marina's appearance, surroundings, conditions in the marina, including safety, sanitation, technical services, etc.

Marinas can receive from 1 to 5 Amber Anchors, with a certain number meaning meeting specific requirements. Safety issues have been precisely defined from level 1 of the Amber Anchor - all presented in Table 2.

Tahle 2. Safety issues in the "Amber Anchors" certification system

\begin{tabular}{|c|c|c|c|c|c|}
\hline \multirow{2}{*}{ Requirement } & \multicolumn{5}{|c|}{ Level - number of Amber Anchors } \\
\hline & 1 & 2 & 3 & 4 & 5 \\
\hline 1 & 2 & 3 & 4 & 5 & 6 \\
\hline Marking the marina from the water side & $x$ & $x$ & $x$ & $x$ & $x$ \\
\hline $\begin{array}{l}\text { Visibly marked: fire-fighting equipment, first-aid kits, emergency ladders from water, waste } \\
\text { point, information point, exits from buildings, marinas, rescue equipment, high voltage }\end{array}$ & $x$ & $x$ & $x$ & $x$ & $x$ \\
\hline Informational board: emergency numbers, person designated by the marina & $x$ & $x$ & $x$ & $x$ & $x$ \\
\hline Clear navigation markings & $x$ & $x$ & $x$ & $x$ & $x$ \\
\hline Fire equipment - serviced and deployed & $x$ & $x$ & $x$ & $x$ & $x$ \\
\hline Access to first aid kits in the marina & $x$ & $x$ & $x$ & $x$ & $x$ \\
\hline Fuels, oils, paints and all similar substances properly stored & $x$ & $x$ & $x$ & $x$ & $x$ \\
\hline Safe mooring (without temporary handles, etc.) & $x$ & $x$ & $x$ & $x$ & $x$ \\
\hline Free accessibility to land and marina infrastructure & $x$ & $x$ & $x$ & $x$ & $x$ \\
\hline
\end{tabular}




\begin{tabular}{|c|c|c|c|c|c|}
\hline 1 & 2 & 3 & 4 & 5 & 6 \\
\hline A berth with access from the shore & $x$ & $x$ & $x$ & $x$ & $x$ \\
\hline Safety ladders on every platform & $x$ & $x$ & $x$ & $x$ & $x$ \\
\hline Lifebuoy on each platform & $x$ & $x$ & $x$ & $x$ & $x$ \\
\hline Marina's liability insurance & & $x$ & $x$ & $x$ & $x$ \\
\hline Night illumination of the marina & & $x$ & $x$ & $x$ & $x$ \\
\hline List of doctors placed on the information board & & $x$ & $x$ & $x$ & $x$ \\
\hline An electrical system certified every year & & $x$ & $x$ & $x$ & $\mathrm{x}$ \\
\hline Night illumination of the marina and platforms & & & $x$ & $x$ & $x$ \\
\hline Keeping records of the boats and people responsible for them & & & $x$ & $x$ & $x$ \\
\hline Staff trained with first aid & & & $x$ & $x$ & $x$ \\
\hline $\begin{array}{l}\text { Documented inspections to ensure safety of navigation/berthing: fire extinguishers, life-saving devices } \\
\text { electrical systems, devices for gray and black sewage, removal of hazardous substances, etc. }\end{array}$ & & & $x$ & $x$ & $x$ \\
\hline Preventive and emergency plan: fire protection, evacuation, medical assistance, fuel and oil leakage & & & $x$ & $x$ & $x$ \\
\hline A general marina and evacuation plan available at the office and the platform & & & $x$ & $x$ & $\mathrm{x}$ \\
\hline Waterways of adequate width to navigate & & & $x$ & $x$ & $\mathrm{x}$ \\
\hline A solid and properly maintained platform & & & $x$ & $x$ & $\mathrm{x}$ \\
\hline The right length and width of the platforms & & & $x$ & $x$ & $x$ \\
\hline Fire equipment available on every platform & & & $x$ & $x$ & $\mathrm{x}$ \\
\hline Notifying the owner, the person responsible for the yacht in case of irregularities & & & & $x$ & $\mathrm{x}$ \\
\hline Facility protection & & & & & $x$ \\
\hline Defibrillator on site & & & & & $\mathrm{x}$ \\
\hline Hospital within 12 minutes by car & & & & & $x$ \\
\hline The marina should have easy entry and exit from the wharf and platform & & & & & $x$ \\
\hline
\end{tabular}

Source: own study based on a full inspection list.

\section{Certification of marinas on the West Pomeranian Sailing Route}

The "Amber Anchors" certification program was introduced in 2015 in ports and marinas, which form the West Pomeranian Sailing Route, are members of ZPIPJ - LOT ZSŻ and wanted to be audited. As a result of the audit, 13 marinas were granted certificates from 3 to 5 Amber Anchors. Table 3 presents the results of certification.

Table 3. Marinas of the West Pomeranian Sailing Route subject to certification

\begin{tabular}{|c|c|c|c|c|c|c|}
\hline Water area & Name of marina & $\begin{array}{c}1 \\
\text { Amber } \\
\text { Anchor }\end{array}$ & $\begin{array}{c}2 \\
\text { Amber } \\
\text { Anchors }\end{array}$ & $\begin{array}{c}3 \\
\text { Amber } \\
\text { Anchors }\end{array}$ & $\begin{array}{c}4 \\
\text { Amber } \\
\text { Anchors }\end{array}$ & $\begin{array}{c}5 \\
\text { Amber } \\
\text { Anchors }\end{array}$ \\
\hline 1 & 2 & 3 & 4 & 5 & 6 & 7 \\
\hline Odra river & Tourist Port, Gryfino & & & $\mathcal{\imath}$ & & \\
\hline \multirow{3}{*}{ Dabie lake } & Dąbie lake Camping Marina PTTK, Szczecin & & & & & 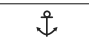 \\
\hline & Marina Pogoń, Szczecin & & & & $\mathcal{\ddagger}$ & \\
\hline & Marina of the Sports and Recreation Center, Lubczyna & & & & & 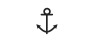 \\
\hline \multirow{5}{*}{$\begin{array}{l}\text { Szczecin } \\
\text { Lagoon }\end{array}$} & Yacht Basin Wolin & & & $\mathcal{\ddagger}$ & & \\
\hline & Marina, Nowe Warpno & & & 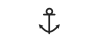 & & \\
\hline & Marina Wolin & & & $\mathcal{\ddagger}$ & & \\
\hline & Yacht Marina on the Mill Channel, Stepnica & & & $\mathcal{\downarrow}$ & & \\
\hline & Yacht Marina in the Fisherman's Basin, Stepnica & & & $\dot{\downarrow}$ & & \\
\hline
\end{tabular}




\begin{tabular}{|c|c|c|c|c|c|c|}
\hline 1 & 2 & 3 & 4 & 5 & 6 & 7 \\
\hline \multirow{4}{*}{ Baltic Sea } & North Pool, Świnoujście & & & & & $\mathcal{j}$ \\
\hline & Marina Solna, Kołobrzeg & & & & & $\mathcal{\downarrow}$ \\
\hline & Marina, Kamień Pomorski & & & & & $\mathcal{j}$ \\
\hline & The Yacht Port, Dziwnów & & & & & $\mathcal{4}$ \\
\hline
\end{tabular}

Source: own study based on ZPiPJ - LOT ZSŻ data.

The facilities indicated in Table 3 were subject to certification in 2015. The number of vessels that visited the marina within one year of obtaining the certificate is presented in Table 4.

Table 4. Number of yachts visiting certified marinas in 2016

\begin{tabular}{|c|c|c|c|c|}
\hline \multirow{3}{*}{ Water area } & \multirow{3}{*}{ Name of marina } & \multicolumn{3}{|c|}{ Year 2016} \\
\hline & & 3 & 4 & 5 \\
\hline & & Amber Anchors & Amber Anchors & Amber Anchors \\
\hline Odra river & Tourist Port, Gryfino & 258 & & \\
\hline \multirow{2}{*}{ Dąie lake } & Marina Pogoń, Szczecin & & 349 & \\
\hline & Marina of the Sports and Recreation Center, Lubczyna & & & 579 \\
\hline \multirow{4}{*}{$\begin{array}{l}\text { Szczecin } \\
\text { Lagoon }\end{array}$} & Yacht Basin Wolin & 720 & & \\
\hline & Marina, Nowe Warpno & 8 & & \\
\hline & Yacht Marina on the Mill Channel, Stepnica & 782 & & \\
\hline & Yacht Marina in the Fisherman's Basin, Stepnica & 544 & & \\
\hline \multirow{3}{*}{ Baltic Sea } & Marina Solna, Kołobrzeg & & & 1382 \\
\hline & Marina, Kamień Pomorski & & & 562 \\
\hline & The Yacht Port, Dziwnów & & & 1324 \\
\hline
\end{tabular}

Source: own study.

Compared to 2015 when no certification processes for marinas were carried out in the West Pomeranian region, the number of yachts moored in the West Pomeranian ports has grown. The comparison of 2015 and 2016 is shown in Figure 2.

Table 5 presents a summary of individual locations, including the amount of capital invested, the number of berths in the marina and the fact of undergoing certification. The data shows that the awareness of certification is independent of whether the facility is a newly built or modernized. The color in the horizontal lines is marked by those locations that were built "from scratch". In 2015, the certification was carried out in the form of a pilot, in the first place for ZPiPJ - LOT ZSŻ members. Adequate data aggregation allows us to state that the newly built marina needs a circulation of funds or one berth in the average amount of PLN 160,477.80. After rejection of the extreme data (Wharf in Gryfino, where most of the funds were directed to the reconstruction of Waterfront), this amount is PLN 144,711.30. The amount of investments for one berth for modernized marinas is PLN 68,266.03. 


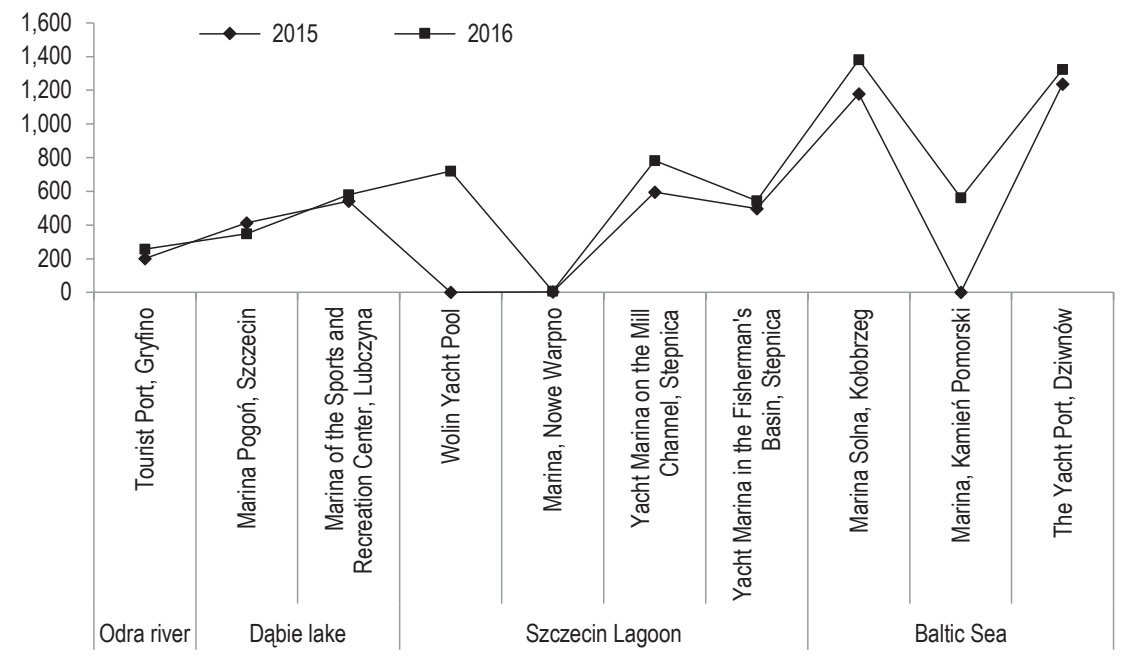

Figure 2. Comparison of the number of visitors -2015 and 2016

Source: own study.

Table 5. Marinas forming the West Pomeranian Sailing Route divided into new and modernized

\begin{tabular}{|c|c|c|c|}
\hline Name/location & Invested funds (PLN) & Number of berths & $\begin{array}{l}\text { Marina's undergoing } \\
\text { certification }\end{array}$ \\
\hline Marina Pogoń & $4,551,370.30$ & 230 & $4 \stackrel{4}{4}$ \\
\hline Yacht Club AZS & $2,112,291.56$ & 110 & - \\
\hline Marina Wapnica - Międzyzdroje & $9,517,910.13$ & 52 & - \\
\hline Yacht Port in Nowe Warpno & $9,675,981.27$ & 52 & $3 \stackrel{4}{4}$ \\
\hline Marina Wolin & $5,197,818.00$ & 60 & $3 \stackrel{4}{4}$ \\
\hline Marina Kamień Pomorski & $20,565,694.79$ & 310 & $5 \stackrel{4}{4}$ \\
\hline Marina at Wyspa Grodzka & $62,453,534.56$ & 74 & - \\
\hline Euroregional Center for Water Education and Sailing & $36,324,639.98$ & 232 & - \\
\hline Water nooks in the area of Lake Dąbie & $1,362,515.28$ & 0 & - \\
\hline Marina Solna in Kołobrzeg & $11,432,247.10$ & 300 & $5 \stackrel{4}{4}$ \\
\hline Yacht Port in Dziwnów & $10,552,292.18$ & 60 & $5 \stackrel{2}{4}$ \\
\hline Yacht Port in Darłowo & $1,971,161.91$ & 67 & - \\
\hline Basen Północny [North Basin] & $12,721,944.54$ & 150 & $5 \stackrel{4}{4}$ \\
\hline Yacht Port in Stepnica (all localisations) & $12,642,847.01$ & 392 & $3 \stackrel{2}{4}$ \\
\hline Yacht Port in Lubczyna & $7,408,761.31$ & 96 & $5 \stackrel{\imath}{4}$ \\
\hline Passenger quay in Gryfino & $14,872,331.26$ & 25 & $3 \stackrel{q}{q}$ \\
\hline Passenger quay at Jana z Kolna in Szczecin & $1,118,017.27$ & 0 & - \\
\hline Yacht Port in Police & $1,962,296.21$ & 10 & - \\
\hline Yacht Port in Dąbie - Marina Hotele & $1,041,902.25$ & 90 & - \\
\hline Total & $227,185,556.91$ & 2310 & \\
\hline
\end{tabular}

Source: own study based on data obtained from the Marshal's Office of West Pomeranian Voivodship, ZPiPJ - LOT ZSŻ and West Pomeranian Regional Tourist Organization. 


\section{Summary}

Sailing, like many other areas, is subject to constant change, in line with the rhythm imposed by progress, demographic changes and the dynamics of economy around the world. The changes are of quantitative and qualitative character. They are related to the opening and expansion of the European market, as well as the increase in its accessibility for new groups of customers which appeared along with the increase of income, elimination of administrative barriers, improvement of communication accessibility (Butowski, 2017, p. 19).

The growing need to confirm the quality of the services offered, and at the same time the basic need to feel safe made marina operators aware of the indispensability of categorizing marinas and ports. The level of assigned categories in the West Pomeranian region (from 3 to 5 ) confirms that the certification program is needed, and marina operators are aware of its value. This is also confirmed by investments and the funds involved in them. Regardless of the financial account, safety issues have priority.

\section{Conclusions}

1. The investments made it possible to meet the minimum standards for the quality of services and safety in marinas and have been prepared for the certification process.

2. The amount to be allocated for creating one berth at the marina is PLN $160,477.80$, while the investment in one berth in the modernized marina is PLN 68,266.03.

3. Marinas that have been subject to certification experience an increase in the number of sailing visitors.

\section{References}

Butowski, L. (2010). Morska turystyka żeglarska w Europie - podstawy metodologiczne analizy jakościowej wybranych elementów popytu i podaży. Folia Turistica, 23, 95-114.

Butowski, L. (2017). Infrastruktura żeglarska na europejskich wodach morskich: geneza, funkcje, struktura, topografia. Ekonomiczne Problemy Turystyki, 2 (38), 19.

http://rpo2007-2013.wzp.pl/rpo/nabory_w_trybie_konkursowym_-_2014/p-r-m-a-22838/5_1_1_infrastruktura_turystyki.htm.

http://rpo2007-2013.wzp.pl/rpo/nabory_w_trybie_konkursowym_-_2014/p-r-m-a-22844/6_1_1_infrastruktura_turystyczna_na_ obszarze_metropolitalnym.htm.

http://rpo2007-2013.wzp.pl/rpo/nabory_w_trybie_konkursowym_-_2012/p-r-m-a-17604/5_1_1_infrastruktura_turystyki.htm.

http://rpo2007-2013.wzp.pl/rpo/nabory_w_trybie_konkursowym_-_2012/p-r-m-a-17605/6_1_1_infrastruktura_turystyki_na_obszarze_ metropolitalnym.htm.

http://rpo2007-2013.wzp.pl/rpo/nabory_w_trybie_konkursowym_-_2012/p-r-m-a-17921/5_1_1_infrastruktura_turystyki.htm.

https://stat.gov.pl/files/gfx/portalinformacyjny/pl/defaultaktualnosci/5494/1/15/1/turystyka_w_2017.pdf.

Strategia rozwoju sektora transportu Województwa Zachodniopomorskiego do roku 2020 (2010). Zarząd Województwa Zachodniopomorskiego, Szczecin.

Woś, K. (2005). Kierunki aktywizacji działalności żeglugi śródlądowej w rejonie ujścia Odry w warunkach integracji Polski z Unią Europejska. Warszawa: Ministerstwo Środowiska.

www.marinas.pl/certyfikacja.

www.turystyka.wzp.pl/programy-strategie-fundusze/program-rozwoju-infrastruktury-portow.

Cite this article aS: Zalewski, T., Bulikowska, M. (2018). Analysis of investment level and marina certification in the process of raising safety standards on the West Pomeranian Sailing Route. European Journal of Service Management, 4 (28/2), 531-539. DOI: 10.18276/ ejsm.2018.28/2-64. 